\title{
Pronunciation of English Dental Fricatives by Slovak University EFL Students
}

\author{
Rastislav Metruk $^{1}$ \\ ${ }^{1}$ Department of English Language and Literature, Faculty of Humanities, University of Žilina, Žilina, Slovakia \\ Correspondence: Rastislav Metruk, Department of English Language and Literature, Faculty of Humanities, \\ University of Žilina, Univerzitná 8215/1, 01026 Žilina, Slovakia. E-mail: rastislav.metruk@gmail.com
}

Received: December 7, 2016 Accepted: December 27, 2016 Online Published: February 9, 2017

doi:10.5539/ijel.v7n3p11 URL: http://dx.doi.org/10.5539/ijel.v7n3p11

\begin{abstract}
The article attempts to explore the difficulties in pronunciation of English dental fricatives by Slovak EFL university students. The primary objective of the study is to examine to what extent Slovak university students mispronounce $[\theta]$ and $[\varnothing]$ and which sounds act as substitutes for the two consonants. A total of 44 Slovak first-year university students whose major was Teaching English Language and Literature delivered unprepared English monologues, which were recorded on a computer. Subsequently, the files were sent to an English native speaker from Canada who performed an auditory analysis of pronunciation errors in the participants' utterances. The results indicate that English dental fricatives pose problems for Slovak EFL learners since a considerable number of participants mispronounced both voiced and voiceless dental fricative consonants. Finally, the study emphasizes the immense significance of pronunciation instruction as this area still appears to be rather neglected in the context of English language teaching in Slovakia.
\end{abstract}

Keywords: English dental fricative, English spirant, erroneous pronunciation, mispronunciation, EFL learner, Slovak university student

\section{Introduction}

Phoneme substitution errors represent a principal source of erroneous pronunciation (Munro, 2008). Replacing certain phonemes for others is typically the direct result of non-existence of particular L2 sounds in the native tongue of a learner. Such substitutions frequently impede intelligibility (Munro, 2008; Zampini, 2008). English dental fricatives are one of the most often mispronounced sounds in the English pronunciation of L2 learners. The dental consonants $[\theta]$ and [ð] do not exist in the majority of languages; therefore, they are overwhelmingly likely to pose difficulties for EFL learners (Celce-Murcia, Brinton, \& Goodwin, 2010).

Several scholars have conducted studies into English pronunciation of Slovak speakers. Repka \& Sabol (1970) carried out a study which explored the problems of Slovak learners of English with English consonants. Similarly, Soudek (1977) introduces the challenges speakers of Slavic languages face when they produce English consonants. Lenhardt (1983) examined how Slovak speakers pronounce the English vowels [ə] and [3:], and Král'ová (2011) analyzed English pronunciation errors with regard to Slovak-English language interference.

Nonetheless, it appears that devoting closer attention specifically to the pronunciation of English dental fricatives by Slovak EFL learners would prove valuable since the information available on this particular subject in the Slovak context is rather sparse. Moreover, conducting a further study into the mispronunciation of English spirants could be of practical importance for both Slovak learners and teachers since English dental fricatives are commonly replaced by a variety of consonants, exhibiting no particular pattern regarding the substitutes.

The objectives of this study are as follows:

- to examine to what extent Slovak learners of English mispronounce dental fricatives;

- $\quad$ to discover which consonants act as substitutes for [ $[\theta]$ and [ð];

- to propose what steps should be taken to decrease the occurrence of mispronouncing English spirants by Slovak EFL learners. 


\section{Literature Review}

\subsection{Pitfalls of Dental Fricatives}

English dental fricatives cause problems for many L2 learners since the majority of EFL learners use a language that does not contain [ $\theta$ ] and [ð] (Burridge, 2005; Čubrovič \& Paunović, 2009; Celce-Murcia Brinton, \& Goodwin, 2010). Maddieson (1984) reports that $[\theta]$ is included in 18 out of 317 examined languages (5.7\%), and [ð] (including the 2 languages which contain the variants of [ð]) is contained in 23 languages (7.3\%). Despite the fact that EFL learners are strongly advised to avoid replacing the two consonants for other sounds, English L2 learners typically substitute $[\theta]$ for $[\mathrm{s}],[\mathrm{f}]$, or $[\mathrm{t}]$ and $[ð]$ for $[\mathrm{d}],[\mathrm{z}]$, or [v] (Celce-Murcia Brinton, \& Goodwin, 2010; Cruttenden, 2014).

English spirants do not exist in the Slovak language. Thus, Slovak learners of English also have a tendency to replace these sounds with other consonants. As Soudek (1977) noted, Slovak speakers substitute [ $\theta]$ for [f] and [ð] for $[\mathrm{dz}]$ or [d]. Ološtiak (2007) regards the Slovak consonants [t] and [s] as frequent substitutes for the voiceless dental fricative and [d] or [z] for the voiced dental fricative. Král'ová (2011) extends the scope of the potential surrogates as the research she conducted demonstrates that the Slovak substitutes for $[\theta]$ were $[\mathrm{t}]$, [f], [s], [d], and [z] respectively, and the substitutes for [ð] were [d], [t], and [z] respectively. Bázlik \& Miškovičová (2012) point out that $[\theta]$ is typically replaced by $[\mathrm{t}],[\mathrm{f}]$, or $[\mathrm{s}]$ and $[ð]$ is frequently substituted for $[\mathrm{d}],[\mathrm{v}]$, or $[\mathrm{z}]$. Apparently, the absence of English spirants in the Slovak sound system plays an instrumental role in mispronouncing the two sounds by EFL learners. Slovak speakers typically replace vowels and consonants which do not exist in their native tongue with L1 phonemes which stand close to the target language sounds (Carter \& Nunan, 2001; Ološtiak, 2007; Hassan, 2014).

\subsection{Characteristics of English Spirants}

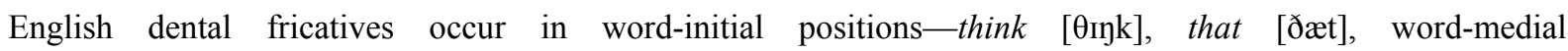

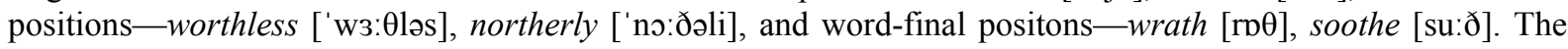
combination of letters "th" is almost always pronounced as $[\theta]$ or [ð]. However, there are instances where letters "th" are pronounced as [t] in words such as Thames [temz] or thyme [tarm]. The voiced pronunciation of "th" is often realized within articles, pronouns, adverbs, adjectives or auxiliary verbs. On the other hand, the voiceless pronunciation of "th" reflects abstract nouns, fractions or ordinal numerals (Brinton \& Brinton, 2010; Bázlik \& Miškovičová, 2012; Cruttenden, 2014).

Spirants are occasionally described as if the tip of the tongue were put between the upper and lower incisors. Therefore, they are sometimes also referred to as interdentals. However, if EFL learners wish to achieve correct and appropriate pronunciation of the two sounds, they ought to place the tongue behind the upper incisors, while the tip of the tongue touches the inner side of the lower incisors. The opening between the tongue and the teeth allows the air to escape (Crystal, 2008; Roach, 2009).

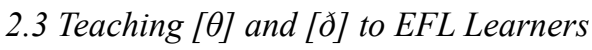

Dental fricatives are not contained within substantial amount of words. Nevertheless, the "th" words are the words with a high frequency of occurrence in the English language such as think, three, Thursday, the, there, they. It should be emphasized that pronouncing these consonants correctly and appropriately does not pose problems for Slovak learners of English. However, the learners encounter difficulties in pronouncing [ $\theta]$ and [ð] when they have to use them automatically and spontaneously. Furthermore, Slovak students are confronted with even knottier problems when dental fricatives stand next to other fricative sounds. Nonetheless, it is interesting that the speakers sometimes pronounce $[\theta]$ and $[ð]$ within instances where dental fricatives do not occur; words such as caterpillar ['kætəpılə] or category ['kætəgəri] are sometimes mispronounced as *['kæӨəpılə] and *['kæOəgəri] (Repka \& Sabol, 1970; Avery \& Ehrlich, 2002; Bázlik \& Miškovičová, 2012).

Students normally learn quickly to recognize the differences between $[\theta]$ or $[ð]$ and their typical substitutes. Proper articulation of dental fricatives is regarded as the most difficult feature of their pronunciation. It is relatively easy to pronounce the two consonants in the word-initial position (e.g., three [ $\theta$ ri] , them [ðem]), more difficult in medial position (e.g., worthless ['w3:Өləs], breathing ['bri:ðın]) and the most difficult in word-final positions (e.g., health [hel $\theta]$, lathe [leIð]). It seems that EFL learners have more difficulties with [ð] than $[\theta]$ in the word-final positions (Lane, 2010).

Teachers are also advised to introduce the simplifications of interdental pronunciation in word-final positions. For instance, sixth [srks $\theta$ ] can be sometimes pronounced as [siks] or [sikst] by English native speakers in casual speech (Wells, 2008). Thus, learners have to be aware of how the dental fricatives are produced in various contexts, and, subsequently, they need to be offered ample opportunities for practicing the two consonants. The 
potential ways of practicing the spirants include exercises such as discovery activities, minimal pairs, repetitions, tongue twisters, or using phonemic charts and dictionaries (Underhill, 2005; Scrivener, 2011).

EFL teachers need to remember that neglecting pronunciation in their classes may have deleterious consequences regarding the pronunciation of their learners. Unfortunately, it appears that more attention is still paid to grammar and lexis despite the fact that pronunciation instruction is also a really essential part of teaching English systems (Pei \& Qin, 2015; Gilakjani \& Sabouri, 2016). Furthermore, motivation as one of the prerequisites for a successful educational process and opportunities for pronunciation practice are also vitally important (Bírová Ocovay, \& Vasbieva, 2016). Therefore, English language teachers shoulder the responsibility for devoting sufficient attention to pronunciation instruction in safe environment, and for ensuring that their pupils and students pronounce English spirants correctly from the very beginning. Otherwise, ELF learners might develop a bad habit of mispronouncing the two sounds, which may be impossible to get out of later in their lives.

\section{Methodology}

The study explores the erroneous pronunciation of English dental fricatives in the pronunciation of Slovak university students. The main aim of the paper is to examine to what degree the spirants are mispronounced, to recognize which consonants serve as substitutes for $[\theta]$ and $[ð]$, and to introduce effective and practical measures to alleviate the problem of mispronouncing the dental sounds in the context of Slovak EFL learners.

\subsection{Participants}

The participants were composed of 44 Slovak first-year university students (38 female and 6 male students - convenience sampling) whose major was Teaching English Language and Literature. They were 21, 5 years old on average, and their native language was Slovak. English pronunciation of the respondents was recorded, and subsequently, the recordings were examined for pronunciation errors by an English native speaker.

\subsection{Assessor}

The assessor was a 47-year old female English native speaker from Montréal, Canada who held the position of a lecturer at a university in Canada. She had received phonetic training when she was taking her PhD. degree in linguistics.

\subsection{Material and Procedure}

The participants were required to deliver an unprepared English monologue of two minutes' duration. They were not limited to any particular subject. A computer and a microphone were used for the purposes of recording the monologues. Afterwards, the recorded files were sent to the assessor for an analysis, including the following instructions: Please, note down what you consider incorrect, inappropriate or strange regarding participants' pronunciation. Provide examples from the recordings, if possible. Do not hesitate to make any remarks and comments on the pronunciation of the respondents. The assessor had not been provided with any background information on the objective of the study and the participants in order to preserve authenticity. Finally, spirant errors which were identified by the assessor were analyzed and examined, and pertinent conclusions were drawn.

\section{Results and Discussion}

\subsection{Errors in Pronouncing Dental Fricatives}

Erroneous pronunciation of English spirants by concrete participants is demonstrated by a black dot in Table 1 below. Furthermore, a consonant which served as an erroneous substitute for both $[\theta]$ and $[ð]$ is shown in square brackets next to the black dot.

Table 1. Mispronunciations of $[\theta]$ and [ð]

\begin{tabular}{lll}
\hline & {$[\theta]$} & {$[\mathrm{d}]$} \\
\hline 1. & & $\bullet[\mathrm{d}]$ \\
2. & & $\bullet[\mathrm{d}]$ \\
3. & & $\bullet[\mathrm{d}]$ \\
4. & $\bullet[\mathrm{t}]$ & $\bullet[\mathrm{d}]$ \\
5. & $\bullet[\mathrm{f}]$ & $\bullet[\mathrm{d}]$ \\
6. & & $\bullet[\mathrm{d}]$ \\
7. & & \\
8. & & $\bullet[\mathrm{d}]$ \\
9. & $\bullet[\mathrm{f}]$ and $[\mathrm{t}]$ & $\bullet[\mathrm{d}]$ \\
\hline 10. & $\bullet[\mathrm{t}]$ & \\
\hline
\end{tabular}




\begin{tabular}{|c|c|c|}
\hline 11. & & \\
\hline 12. & & - [d] \\
\hline 13. & & \\
\hline 14. & & \\
\hline 15. & - $[\mathrm{t}]$ & - [d] \\
\hline 16. & - $[t]$ & - [d] \\
\hline 17. & & - [d] \\
\hline 18. & - $[\mathrm{f}]$ and $[t]$ & - [d] \\
\hline 19. & & - [d] \\
\hline 20. & - $[\mathrm{f}]$ & \\
\hline 21. & - $[\mathrm{t}]$ & \\
\hline 22. & & \\
\hline 23. & & - [d] \\
\hline 24. & - $[\mathrm{t}]$ & - [d] \\
\hline 25. & & \\
\hline 26. & & - [d] \\
\hline 27. & $\bullet$ [f ] & \\
\hline 28. & & - [d] \\
\hline 29. & & \\
\hline 30. & $\bullet[\mathrm{f}]$ & \\
\hline 31. & & - $[\mathrm{t}]$ \\
\hline 32. & & \\
\hline 33. & & \\
\hline 34. & - $[\mathrm{t}]$ & \\
\hline 35. & - $[\mathrm{f}]$ and $[\mathrm{t}]$ & - [d] \\
\hline 36. & $\bullet[\mathrm{f}]$ & \\
\hline 37. & - $[f]$ & \\
\hline 38. & & \\
\hline 39. & & - [d] \\
\hline 40. & & \\
\hline 41. & & \\
\hline 42. & & \\
\hline 43. & - $[\mathrm{t}]$ & \\
\hline 44. & & $\bullet$ [d] \\
\hline Total & $17(39 \%)$ & $22(50 \%)$ \\
\hline
\end{tabular}

A total of 17 participants (39\%) mispronounced consonant [ $\theta$ ], and half of them mispronounced consonant [ð]. A preponderance of the errors in pronouncing the voiceless dental fricative occurred at the word-medial and

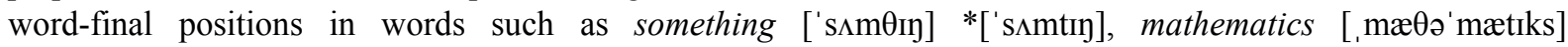

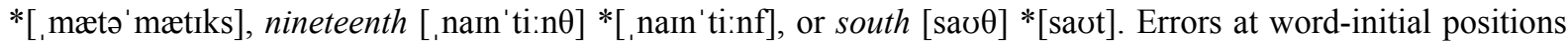

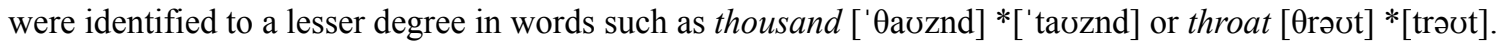

The overwhelming majority of errors in pronouncing the voiced spirant took place at word-initial positions in words such as the [ðə] *[də] or these [ði:z]*[di:z]. Mispronunciations of [ð] in medial-word positions were identified to a smaller extent in words such as other [' $\Lambda$ ðə] *[' $\Lambda$ də] or father ['fa:ðə] *['fa:də].

\subsection{Substitute Phonemes}

Two sounds were identified as substitutes for [ $\theta]$; consonants [t] and [f] respectively were recognized by the

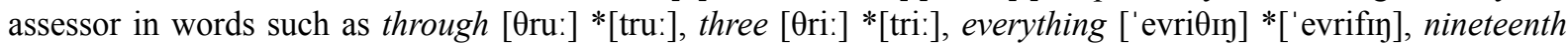
[, nain'ti:n $\theta] *[$, nain'ti:nf].

Interestingly, 3 of the 18 participants (participants number $9,18,35$ ) who mispronounced phoneme [ $\theta]$ used both [t] and [f] instead of the voiceless spirant in their utterances. It seems that no regular pattern can be detected as regards the usage of the two substitutes. The remaining 14 participants adhered only to one erroneous substitute. Altogether, phoneme [t] occurred in 11 instances, which accounted for 55\%, and substitute phoneme [f] occurred in 9 instances, constituting $45 \%$ of the total amount of 20 occurrences.

Voiced dental fricative [ð] was replaced by [d] (95\%) and [t] (5\%). Voiceless alveolar plosive consonant [t] was only used by participant 31 . 


\subsection{Results Interpretation}

It is apparent that dental fricatives pose grave problems for Slovak EFL learners since 39\% of the participants mispronounced the voiceless spirant, and 50\% pronounced erroneously its voiced counterpart. Therefore, it can be concluded that both $[\theta]$ and $[ð]$ were mispronounced by the participants to a substantial degree.

Taking the substitute phonemes into account, consonants [t] and [f] acted as substitutes for [ $\theta]$. Consonants [d] and [t] were used as a replacement for [ð]. However, [t] only had one occurrence; thus, the vast majority used [d] instead of $[ð]$.

Surprisingly, consonant $[\mathrm{s}]$ has not been identified at all despite the fact that this voiceless alveolar fricative sound is frequently used as a replacement for the voiceless spirant. Similarly, the voiced dental fricative has not been replaced by $[\mathrm{z}]$ although this voiced alveolar consonant can be habitually heard in the English utterances of Slovak EFL learners as a replacement for [ð] (Ološtiak, 2007; Celce-Murcia Brinton, \& Goodwin, 2010; Králová, 2011; Bázlik \& Miškovičová 2012). Obviously it would be very difficult to establish a regular pattern with regard to the exact amount of possible substitutes for English spirants.

Undoubtedly, EFL teachers occupy a pivotal role as far as the mispronunciation of dental fricatives is concerned. They need to remember that pronunciation instruction cannot be overlooked and omitted from the curriculum since neglecting such an important area in teaching English could have dire consequences. Devoting assiduous attention to sounds which do not have their counterparts in the native tongue of Slovak learners such as $[\theta]$ and $[ð]$ would significantly eliminate the difficulties L2 learners encounter.

\section{Conclusion}

The study indicates that pronunciation problems with English dental fricatives in the Slovak context still persist. Two substitute sounds - consonants [ $\mathrm{t}$ ] and [f] were identified by the assessor as far as the erroneous pronunciation of the voiceless dental fricative is concerned. Taking the voiced spirant into account, voiced alveolar consonant [d] was identified as the main substitute, while its voiceless counterpart [t] occurred only on one occasion. However, difficulties with dental fricatives appear to remain unresolved since a high number of mispronunciation instances were detected. Moreover, possible substitutes may vary from one study to another. Therefore, conducting a further examination of English spirants in the pronunciation of Slovak speakers would seem valuable.

Tackling problems with English spirants appears to be a formidable and unenviable task English language teachers need to undertake if the occurrence of mispronouncing these two consonants by Slovak EFL learners is to be decreased. Appropriate phonetic practice along with the preparation of relevant and effective pronunciation activities seems to be a vital part of the teaching process. Both teachers and learners need to remember that replacing certain sounds for others hinders communication and often poses a threat to intelligibility. Therefore, pronunciation instruction definitely has to be incorporated into the teaching/learning process.

In conclusion, it should be emphasized that performing further research in this area on a larger number of participants, employing a higher amount of assessors would prove beneficial to both Slovak teachers and learners.

\section{References}

Avery, P., \& Ehrlich, S. (2002). Teaching American English Pronunciation. New York: Oxford University Press.

Bázlik, M., \& Miškovičová, J. (2012). Pravidlá výslovnosti britskej a americkej angličtiny. Bratislava: Iura Edition.

Bírová, J., Ocovay, J., \& Vasbieva, D. (2016). Implementation of New Teaching Technologies during the Action Research by Experienced Language Teachers. IEJME_Mathematics Education, 11(8), 3089-3103. Retrieved from http://iejme.com/makale/921

Brinton, J., \& Brinton, M. (2010). The Linguistic Structure of Modern English. Philadelphia: John Benjamins Publishing Company. https://doi.org/10.1075/z.156

Burridge, K. (2005). Weeds in the Garden of Words. Further Observations on the Tangled History of the English Language. Cambridge: Cambridge University Press. https://doi.org/10.1017/CBO9780511486982

Carter, R., \& Nunan, D. (2001). The Cambridge Guide to Teaching English to Speakers of Other Languages. Cambridge: Cambridge University Press. https://doi.org/10.1017/CBO9780511667206

Celce-Murcia, M., Brinton, D., \& Goodwin, J. (2010). Teaching Pronunciation. A Reference for Teachers of English to Speakers of Other Languages. Cambridge: Cambridge University Press. 
Cruttenden, A. (2014). Gimson's Pronunciation of English (8th ed.). London: Routledge.

Crystal, D. (2008). A Dictionary of Linguistics and Phonetics (6th ed.). Malden: Blackwell Publishing. https://doi.org/10.1002/9781444302776

Čubrovič, B., \& Paunović, T. (Eds.). (2009). Talking English Phonetics across Frontiers. Newcastle upon Tyne: Cambridge Scholars Publishing.

Gilakjani, A., \& Sabouri, N. (2016). Why is English Pronunciation Ignored by EFL Teachers in Their Classes? International Journal of English Linguistics, 6(6). http://dx.doi.org/10.5539/ijel.v6n6p195

Hassan, E. (2014). Pronunciation Problems: A case Study of English Language Students at Sudan University of Science and Technology. English Language and Literature Studies, 4(4). http://dx.doi.org/10.5539/ells.v4n4p31

Králová, Z. (2011). Slovensko-anglická zvuková interferencia. Žilina: EDIS.

Lane, L. (2010). Tips for Teaching Pronunciation. A Practical Approach. Upper Saddle River: Pearson Longman.

Lenhardt, J. (1983). Adaptácia anglických vokalických zvukov [ə] and [3:] v slovenčine. Slovenská reč, 48, 160-167.

Maddieson, I. (1984). Patterns of Sounds. Cambridge: Cambridge University Press.

Munro, M. J. (2008). Foreign Accent and Speech Intelligibility. In H. Edwards, G. Jette, \& M. L. Zampini (Eds.), Phonology and Second Language Acquisition (pp. 193-218). Amsterdam: John Benjamins. https://doi.org/10.1075/sibil.36.10mun

Ološtiak, M. (2007). Jazykovoštruktúrny a komunikačno-pragmatický status vlastného mena (adaptácia anglických proprií $v$ slovenčine). Prešov: Filozofická fakulta Prešovskej univerzity. Retrieved from http://olostiak.webz.cz/Publikovane/propria_monografia_2007.pdf

Pei, Z., \& Qin, K. (2015). A Survey o English Phonetics Instruction in China. International Journal of English Linguistics, 5(5). http://dx.doi.org/10.5539/ijel.v5n5p75

Repka, R., \& Sabol, J. (1970). Niektoré problémy osvojovania si výslovnosti anglických spoluhlások slovenskými študentmi. Zborník prác Krajského pedagogického ústavu v Prešove, 149-153. Prešov: Krajský pedagogický ústav.

Roach, P. (2009). English Phonetics and Phonology. Cambridge: Cambridge University Press.

Scrivener, J. (2011). Learning Teaching. Oxford: Macmillan Education.

Soudek, I. (1977). Error analysis and the System of English Consonants. ELT Journal, 31(2), 125-130. https://doi.org/10.1093/elt/XXXI.2.125

Underhill, A. (2005). Learning and Teaching Pronunciation. Oxford: Macmillan.

Wells, J. (2008). Longman Pronunciation Dictionary (3th ed.). Harlow: Pearson Longman.

Zampini, M. L. (2008). L2 Speech Production Research. In H. Edwards, G. Jette, \& M. L. Zampini (Eds.), Phonology and Second Language Acquisition (pp. 219-249). Philadelphia: John Benjamins. https://doi.org/10.1075/sibil.36.11zam

\section{Copyrights}

Copyright for this article is retained by the author(s), with first publication rights granted to the journal.

This is an open-access article distributed under the terms and conditions of the Creative Commons Attribution license (http://creativecommons.org/licenses/by/4.0/). 